International Journal of Current Advanced Research

ISSN: O: 2319-6475, ISSN: P: 2319 - 6505, Impact Factor: SJIF: 5.995

Available Online at www.journalijcar.org

Volume 6; Issue 5; May 2017; Page No. 3716-3718

DOI: http://dx.doi.org/10.24327/ijcar.2017.3718.0353

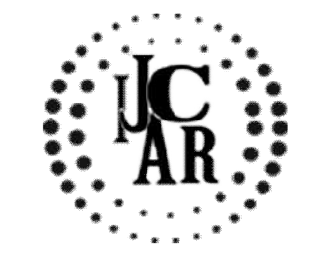

Research Article

\title{
DERMATITIS MEDICAMENTOSA- A RARE CASE OF ADVERSE DRUG REACTION DUE TO SITAGLIPTIN
}

\section{Pradeep selvaraj ${ }^{1}$, Preethi $S^{2}$ and Selvaraj $\mathbf{I}^{3}$}

\author{
${ }^{1}$ Department of Community Medicine, SRM MCH\&RC, Kattankulathur \\ ${ }^{2}$ Department of Community Medicine, Yenepoya Medical College, Deralakatte \\ ${ }^{3}$ Department of community medicine, Mount. Zion Medical College, Adoor
}

\section{A R T I C L E I N F O}

\section{Article History:}

Received $20^{\text {th }}$ February, 2017

Received in revised form $12^{\text {th }}$ March, 2017

Accepted $15^{\text {th }}$ April, 2017

Published online $28^{\text {th }}$ May, 2017

\section{Key words:}

Sitagliptin, Type 2 diabetes, fixed drug reaction,

Hyperpigmentation, Adverse drug reaction

\begin{abstract}
A B S T R A C T
Skin being the largest organ of the body accounts for two-three percent of all adverse drug reactions. Acute cutaneous drug induced reactions are caused by ingestion, inhalation or insertion of a drug and also due to allergic sensitization reactions to drugs applied to the cutaneous surface. We hereby report a case of sitagliptin (oral hypoglycemic drug) induced cutaneous adverse drug reaction in a 61 year old female who developed generalized hyper pigmentation worsening on exposed areas within two months of initiation of sitagliptin. The lesions started resolving on cessation of the drug. Dermatitis medicamentosa due to sitagliptin is very rare and first of such case is being reported in India at the time of diagnosis.
\end{abstract}

Copyright $(2017$ Pradeep selvaraj., Preethi S and Selvaraj I. This is an open access article distributed under the Creative Commons Attribution License, which permits unrestricted use, distribution, and reproduction in any medium, provided the original work is properly cited.

\section{INTRODUCTION}

It's indeed alarming to know the increasing diabetic population trend in India and simultaneously expanding various approaches of treatment from different health care workers existing in our society. The current diabetic age standardized death rate in India is 26.3 per $1,00,000$ population. ${ }^{1}$ Sitagliptin is the first selective antagonist of dipeptidylpeptidase-4 which improves the glycemic control in type 2 diabetes since FDA approved on 2006. ${ }^{2}$ Acute cutaneous drug induced reactions are caused by ingestion, inhalation or insertion of a drug and also as a result of allergic sensitization reactions to drugs applied to the cutaneous surface. We are going to discuss a case of sitagliptin induced dermatitis medicamentosa or cutaneous adverse drug reaction which is very rare and first of such case is being reported in India at the time of diagnosis.

\section{Case History}

A 61 year old woman with primary level of education, home maker by occupation and a known case of type II diabetes mellitus since ten years came to our clinic with complaints of uncontrolled blood sugar levels, benign paroxysmal positional vertigo, dragging pain on both legs with burning and tingling sensation over the feet. On taking the detailed history, it was revealed that the patient was not compliant to bimodal

*Corresponding author: Pradeep selvaraj

Department of Community Medicine, SRM MCH\&RC, Kattankulathur treatment including allopathic (sulfonylurea and metformin $500 \mathrm{mg}$ twice daily) ayurvedic treatment for past five years. She was subjected to laboratory tests including complete blood count, glycemic profile, biochemistry profile which revealed hypochromic anemia, hyperglycemia, dyslipdemia, microalbuminuria and raised renal parameters [Table 1]. In view of her poor glycemic control she was started on with sulfonylurea (glyclazide XR 60mg twice daily) and with a combination dose of sitagliptin 50mg with metformin 500mg twice daily. She came for follow up after 15 days and complained of two episodes of low sugar for past few days. Physician then withheld sulfonylurea and continued her on combination dose of sitagliptin 50mg with metformin 500mg twice daily, dietary modification and self care management and advised her to come for follow up every month with blood sugar evaluation including fasting blood sugar (FBS) and post prandial blood sugar (PPBS) levels. She came for follow up after a period of three months with FBS- $161 \mathrm{mg} / \mathrm{dl}$ and PPBS- $235 \mathrm{mg} / \mathrm{dl}$. Hence, Physician restarted her with mild dose of sulfonylurea (glipizide $2.5 \mathrm{mg}$ ) twice daily and continued with combination dose of sitagliptin $50 \mathrm{mg}$ with metformin 500mg twice daily and further advised her to come for follow up every month. She returned again after a gap of four months with generalized hyper pigmentation of upper limbs, face and neck (mainly exposed areas) which she noticed lately progressing for past four months and neglected by not reporting to the physician early [Figure 1,2]. As per patient's words, she initially started noticing hyperpigmentation after two months of initiation of 
sitagliptin. There was no history of any other drug intake prior to the hyperpigmentation in the past. dermatologist and further advised her to come for follow every month. She came back for follow up after a gap of six

Table 1 Investigation trends of the subject during the course of treatment

\begin{tabular}{|c|c|c|c|c|}
\hline Test Name & $\begin{array}{c}\text { Before starting } \\
\text { Sitagliptine } \\
(10 / 12 / 13) \\
\end{array}$ & $\begin{array}{c}\text { Continuing } \\
\text { Sitagliptine } \\
12 / 7 / 14 \\
\end{array}$ & $\begin{array}{c}\text { After stopping } \\
\text { sitagliptine } \\
28 / 01 / 15 \\
\end{array}$ & Reference Range \\
\hline Hemoglobin & $10.0 \mathrm{mg} / \mathrm{dl}$ & $12.0 \mathrm{mg} / \mathrm{dl}$ & $12.0 \mathrm{mg} / \mathrm{dl}$ & $11.5-16.5$ \\
\hline $\begin{array}{l}\text { Blood sugar } \\
\text { Fasting } \\
\text { Post Prandial }\end{array}$ & $\begin{array}{l}261 \mathrm{mg} / \mathrm{dl} \\
293 \mathrm{mg} / \mathrm{dl}\end{array}$ & $\begin{array}{l}135 \mathrm{mg} / \mathrm{dl} \\
178 \mathrm{mg} / \mathrm{dl}\end{array}$ & $\begin{array}{l}118 \mathrm{mg} / \mathrm{dl} \\
160 \mathrm{mg} / \mathrm{dl}\end{array}$ & $\begin{array}{l}70-110 \\
70-140\end{array}$ \\
\hline $\begin{array}{c}\text { HBA1C } \\
\text { Lipid profile }\end{array}$ & $8.2 \%$ & $6.6 \%$ & $7.5 \%$ & $4-6 \%$ \\
\hline T.Cholesterol & $324 \mathrm{mg} / \mathrm{dl}$ & $223 \mathrm{mg} / \mathrm{dl}$ & $181 \mathrm{mg} / \mathrm{dl}$ & $140-200 \mathrm{mg} / \mathrm{dl}$ \\
\hline TGL & $197 \mathrm{mg} / \mathrm{dl}$ & $105 \mathrm{mg} / \mathrm{dl}$ & $159 \mathrm{mg} / \mathrm{dl}$ & $45-165 \mathrm{mg} / \mathrm{dl}$ \\
\hline HDL & $40 \mathrm{mg} / \mathrm{dl}$ & $40 \mathrm{mg} / \mathrm{dl}$ & $34 \mathrm{mg} / \mathrm{dl}$ & $45-65 \mathrm{mg} / \mathrm{dl}$ \\
\hline LDL & $245 \mathrm{mg} / \mathrm{dl}$ & $163 \mathrm{mg} / \mathrm{dl}$ & $108 \mathrm{mg} / \mathrm{dl}$ & $70-130 \mathrm{mg} / \mathrm{dl}$ \\
\hline VLDL & $39 \mathrm{mg} / \mathrm{dl}$ & $20 \mathrm{mg} / \mathrm{dl}$ & $39 \mathrm{mg} / \mathrm{dl}$ & $10-40 \mathrm{mg} / \mathrm{dl}$ \\
\hline $\begin{array}{l}\text { Urine Biochemistry } \\
\text { Microalbumin Spot } \\
\text { Blood Biochemistry }\end{array}$ & $\begin{array}{l}214.1 \mathrm{ug} / \mathrm{mg} \text { of } \\
\text { creatinine }\end{array}$ & $\begin{array}{l}340.0 \mathrm{ug} / \mathrm{mg} \text { of } \\
\text { creatinine }\end{array}$ & $123.8 \mathrm{ug} / \mathrm{mg}$ of creatinine & $\begin{array}{l}<20 \mathrm{ug} / \mathrm{mg} \text { of } \\
\text { creatinine }\end{array}$ \\
\hline Amyalse & $67.0 \mathrm{U} / \mathrm{L}$ & $83.1 \mathrm{U} / \mathrm{L}$ & $78.1 \mathrm{U} / \mathrm{L}$ & $28-100 \mathrm{U} / \mathrm{L}$ \\
\hline Lipase & $87.2 \mathrm{U} / \mathrm{L}$ & $69.0 \mathrm{U} / \mathrm{L}$ & $67.0 \mathrm{U} / \mathrm{L}$ & $13-60 \mathrm{U} / \mathrm{L}$ \\
\hline Urea & $38 \mathrm{mg} / \mathrm{dl}$ & $30 \mathrm{mg} / \mathrm{dl}$ & $42 \mathrm{mg} / \mathrm{dl}$ & $10-40$ \\
\hline Creatinine & $1.3 \mathrm{mg} / \mathrm{dl}$ & $1.2 \mathrm{mg} / \mathrm{dl}$ & $1.0 \mathrm{mg} / \mathrm{dl}$ & $0.4-1.3$ \\
\hline
\end{tabular}

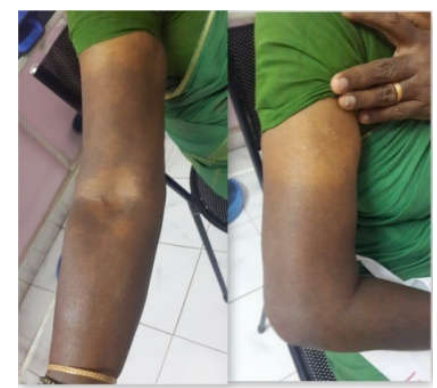

Figure 1 Picture showing hyperpigmentation of right arm during the course of Sitagliptin.

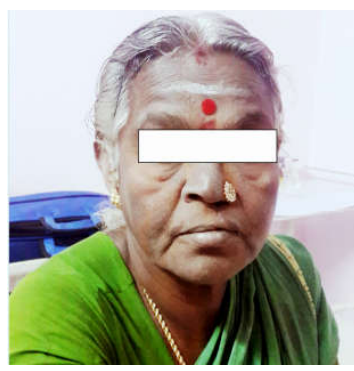

Figure 2 Picture showing hyperpigmentation of face during the course of Sitagliptin.

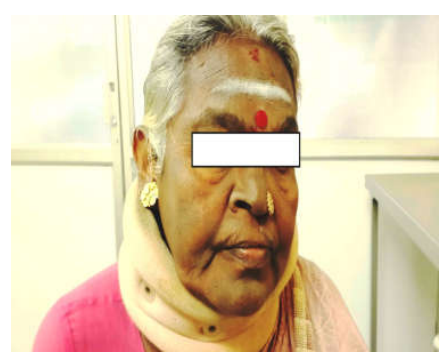

Figure 3 Picture showing the face post cessation of Sitagliptin.

She was referred to a dermatologist for expert opinion, he opined and diagnosed as fixed drug eruption at this juncture and he suggested it could be due to SULPHA group of antibiotics and NSAID group of drugs. She returned back to our clinic after a gap of two weeks, and for safety precaution we stopped her on DPP-4 inhibitor (sitagliptin) and continued her on mild dose of sulfonylurea and metformin twice daily, advised her to continue the topical medications as advised by months and on examination revealed hyper pigmentation has remarkably reduced on both upper limbs and face [Figure 3]. As of now, the patient is having good glycemic control with alpha glucosidase inhibitor (voglibose $0.2 \mathrm{mg}$ ) and metformin $500 \mathrm{mg}$ thrice daily with no further recurrence of such symptoms.

\section{DISCUSSION}

Sitagliptin is a modern drug developed for the management of type II diabetes mellitus approved by the US Food and Drug Administration in 2006 or the European Medicines Agency. Sitagliptin which is a DPP-4 dipeptidyl-peptidase inhibitor effective in lowering HBA1c, fasting as well as postprandial glucose whose action is mediated by increasing the levels of Incretin hormones Glucagon-like-peptide-1 (GLP-1) and Gastric inhibitory polypeptide (GIP). ${ }^{3}$ Sitagliptin with metformin tablets in fixed-dose combinations is used for the treatment of type 2 diabetes when: HBA1C is $>7 \%$, despite use of metformin, and when a combination of metformin and a sulfonylurea is contraindicated or not tolerated. ${ }^{4}$ Twenty six serious skin reactions including two cases of Stevens-Johnson syndrome and two cases of toxic epidermal necrolysis, fifteen anaphylaxis, four angioedema, and three cutaneous vasculitis were confirmed. ${ }^{5}$ Nakai et al had reported a case of a maculopapular eruption caused by sitagliptin phosphate hydrate in a 63 year old women. ${ }^{6}$ Yet another study done by Nakatani et al reported generalized skin eruption with strong itching which was induced by sitagliptin in a patient almost six months after initiation of the drug. ${ }^{7}$ Very few studies have reported fixed drug eruption due to sitagliptin. A study done by Gupta et al revealed sitagliptin induced fixed drug eruption in a 46 year old female who developed circumscribed, erythematous macules all over the body within one week of initiation of drug was the only Indian study found in the literature. ${ }^{8}$ Sitagliptin improves serum triglycerides and high density lipoprotein levels in patients with type 2 diabetes mellitus. ${ }^{9}$ In our case the diagnosis was made from medical history and clinical course. Generalized hyperpigmentation due to sitagliptin in our case was first of its kind in the literature and indeed there was good 
improvement in lipid profiles during the course of treatment with this drug.

\section{CONCLUSION}

In this present case generalized hyperpigmentation would have been induced by cutaneous adverse drug reaction to sitagliptin. Diabetologist and physicians need to be cautious while introducing this drug in managing diabetic patients as various adverse drug events due to this drug have been reported in recent times.

\section{References}

1. Diabetes, deaths per 100000 Data by country. Global Health Observatory data repository. WHO 2015. Available from: http://apps.who.int/gho/data/ node.main.A865DIABETES?lang=en. Last accessed on $5^{\text {th }}$ Feb, 2016.

2. Scheen AJ, Van Gaal LF. Sitagliptine (Januvia): incretin enhancer potentiating insulin secretion for the treatment of type 2 diabetes. Revue medicale de Liege. 2008; 63 Suppl 2:105-9.

3. Gallwitz B. Review of sitagliptin phosphate: a novel treatment for type 2 diabetes. Vasc Health Risk Manag. 2007; 3 Suppl 2: 203-10.
4. Sitagliptin with metformin (Janumet) fixed-dose combination tablets PBS listed for type 2 diabetes mellitus. Published in NPS RADAR. Date published: 01 August 2009. Available from: http://www.nps.org.au/publications/healthprofessional/nps-radar/2009/august-2009/brief-itemsitagliptin. Last accessed on 5th Feb 2016.

5. Desai S, Brinker A, Swann J, Iyasu S. Sitagliptinassociated drug allergy: review of spontaneous adverse event reports. Arch Intern Med 2010; 170:1169-71.

6. Nakai N, Katoh N. Maculopapular-Type Drug Eruption Caused by Sitagliptin Phosphate Hydrate: A Case Report and Mini-Review of the Published WorkAllergology International. 2014; 63:489-91.

7. Nakatani K, Kurose T, Hyo T, Watanabe K, Yabe D, Kawamoto T, Seino Y. Drug-induced generalized skin eruption in a diabetes mellitus patient receiving a dipeptidyl peptidase-4 inhibitor plus metformin. Diabetes Therapy. 2012; 3 Suppl 1:1-5.

8. Gupta M, Gupta A. Fixed drug eruption to sitagliptin. Journal of Diabetes \& Metabolic Disorders. 2015; 14 Suppl 1:1.

9. Fan M, Li Y, Zhang S. Effects of Sitagliptin on Lipid Profiles in Patients with Type 2 Diabetes Mellitus: A Meta-analysis of Randomized Clinical Trials. Medicine. 2016; 95 Suppl 2:e2386.

\section{How to cite this article:}

Pradeep selvaraj., Preethi S and Selvaraj I (2017) 'Dermatitis Medicamentosa- A Rare Case Of Adverse Drug Reaction Due To Sitagliptin', International Journal of Current Advanced Research, 06(05), pp. 3716-3718.

DOI: http://dx.doi.org/10.24327/ijcar.2017.3718.0353 